\title{
Influence of minoxidil on ischemic cutaneous flaps in rats ${ }^{1}$
}

\author{
Influência do minoxidil sobre retalhos cutâneos isquêmicos em ratos
}

\author{
Rogério de Castro Bittencourt ${ }^{2}$, Maria de Lourdes Pessole Biondo-Simões ${ }^{3}$, Josué Brunginski de Paula ${ }^{4}$, Juliano \\ Martynetz ${ }^{5}$ Anne Groth ${ }^{6}$ \\ 1. Master thesis abstract presented to Surgical Clinics Postgraduate Program of Catholic University of Paraná (PUCPR). \\ 2. Surgical Clinics Postgraduate Program of Catholic University of Paraná (PUCPR) student. Plastic Surgery Program Director of Cajuru \\ University Hospital - PUCPR. Member of the Brazilian Society of Plastic Surgery. \\ 3. Experimental Surgery Doctor UNIFESP-EPM. Research Methods Professor - PUCPR. General Surgery Professor - UFPR. Member of \\ CBC and SOBRADPEC. \\ 4. Surgical Tecniques and Experimental Surgery Professor - PUCPR. \\ 5. Medical student - PUCPR. \\ 6. Aspirant member of Brazilian Society of Plastic Surgery.
}

\begin{abstract}
Purpose: To evaluate the influence of minoxidil, a well known vasodilator, on ischemic flap necrosis prevention in rats. Methods: Ventral cutaneous flaps, measuring $8 x 4 \mathrm{~cm}$, were designed in 20 Wistar rats based on the right cranial epigastric artery. In the experiment group, $50 \mathrm{mg} / \mathrm{kg} /$ day of minoxidil sulfate was administered by orogastric tube and the same amount of saline solution was administered to the control group. Such procedure was initiated 24h before surgery and kept once a day through the $7^{\text {th }}$ postoperative day. Microcirculation was evaluated with laser fluxometry $24 \mathrm{~h}$ before surgical procedure, at immediate postoperative and at the $7^{\text {th }}$ postoperative day. Flap necrosis area was evaluated by 2 methods: planimetry and weight/paper ratio. Results: A significant flow increase in distal and medial extremity at M1 (medial point 1) $(p=0,0484)$ was observed in the experiment group. There was significant difference in flap necrosis prevention in the experiment group ( $\mathrm{p}=0,0433)$, although after necrosis took place there was no significant difference in necrosis size. ( $p=0,1051$ and $p=0,2799$ ).Conclusion: Minoxidil sulfate is effective in avoiding necrosis in ischemic flaps, but after necrosis is present there is no difference in survival area between experimental and control groups.
\end{abstract}

Key words: Surgical Flaps. Vasodilator Agents. Minoxidil. Wound Healing. Rats.

\section{RESUMO}

Objetivos: Avaliar a influência do minoxidil, um vasodilatador, na prevenção de necrose, em retalhos isquêmicos, em ratos. Métodos: Preparam-se retalhos cutâneos ventrais, medindo 8x4 cm, baseados na artéria epigástrica cranial direita, em 20 ratos - Wistar. Administrou-se $50 \mathrm{mg} / \mathrm{kg} / \mathrm{dia}$ de sulfato de minoxidil aos ratos do grupo experimento e o mesmo volume de solução salina isotônica aos do grupo controle, por sonda oro-gástrica. Iniciou-se o tratamento 24 horas antes da operação e manteve-se, diariamente, por 7 dias, no pós-operatório. Realizou-se a avaliação da microcirculação dos retalhos fluxometria a laser 24 horas antes da operação, no pós-operatório imediato e após 7 dias. Desenhou-se a área de necrose do retalho em molde e avaliou-se em relação ao tamanho total por 2 métodos: planimetria e peso/papel. Resultados: Constatou-se aumento de fluxo na extremidade distal e medial (M1) ( $\mathrm{p}=0,0484)$, no grupo experimento. Houve diferença na prevenção da necrose nos retalhos do grupo experimento $(\mathrm{p}=0,0433)$, porém quando esta se instalou, não houve diferença quanto ao tamanho da área necrosada ( $\mathrm{p}=0,1051$ e $\mathrm{p}=0,2799)$. Conclusão: $\mathrm{O}$ uso de minoxidil é efetivo para evitar a instalação da necrose de retalhos potencialmente isquêmicos, porém, quando o processo se instala, não existe diferença na sobrevida destes, com a dose e a via empregadas neste estudo, em ratos.

Descritores: Retalhos Cirúrgicos. Vasodilatadores. Minoxidil. Cicatrização de Feridas. Ratos.

\section{Introduction}

Cutaneous flap necrosis is a major complication due to its irreversibility, which leads to partial or total loss of the flap, and consequently undesirable results mainly in plastic surgery. Multiple factors are involved in flap loss, and the basic causes are venous congestion and arterial insufficiency. Several mechanisms act in the process of ischemia, vasoactive substances promoting vasospasm, free radicals production, sodium - potassium pump inactivation, endothelial cells edema, which lead to arterial and venous thrombosis. Many methods have been used to increase cutaneous flap viability. Besides surgical methods, several pharmacological agents with different action mechanisms have been used to increase flap survival. According to Rohrich et al. ${ }^{1}$, to be effective a substance must have the following characteristics: possible to be evaluated clinically, easy administration, high therapeutic action, reproducible results, not expensive, known mechanism of action, allow exclusive use in the post 
operative period, have established bioevaluation, and prevent completely necrosis. These characteristics are not encountered in a sole substance, and the lack of an effective drug capable of ameliorating the survival of cutaneous flaps is what stimulates the research and development of the pharmaceutical companies. Minoxidil (3-óxido-2.4-diamino6-piperidinopyrimidine) is a strong peripheral vasodilator drug (molecular weight 209,5). Its active substance (minoxidil sulfate) causes dilatation of arterioles, but not of veins, by opening the potassium channels. Minoxidil is also used for the treatment of hypertension. Nowadays it is widely used for the treatment of baldness because of its abilities as cutaneous vasodilator and also by its availability for administration per oral or topically. The cutaneous vasodilation of minoxidil is associated with an increase in blood flow to the potentially ischemic cutaneous flaps, therefore augmenting its viability. Animal studies have demonstrated that minoxidil is concentrated in the smooth muscle of the aorta, femoral arteries and other great vessels no matter the route by which it is administrated. It was also observed that it activates the rennin-angiotensin system, causing sodium and water retention. Despite the potential benefits of minoxidil to increased the viability of cutaneous flaps, Smith and Dolan did not show effective results with the use of topic minoxidil $2 \%$ on the survival of dorsal skin flaps in rats ${ }^{(10)}$. Them aim of this study is to evaluate the effect of oral minoxidil in the prevention of the necrosis of ventral ischemic flaps in rats.

\section{Methods}

This study was approved by the Federal Law number 6.638 according to the orientations of the Brazilian College of Animal Experimentation. The Project was approved by the PUCPR Animal Care Ethics Committee. Twenty male Wistar rats (Rattus norvegicus albinus, Rodentia mammalia), 100 to 120 days old, weighing 250 to $350 \mathrm{~g}$ $(285,98 \mathrm{~g} \pm 24,20 \mathrm{~g})$ from the PUCPR animal care department were used in the experiment. The animals received standard chow diet and tap water ad libitum during all the experiment. The animals were randomized in 2 groups of 10 rats. The study group received $50 \mathrm{mg} / \mathrm{kg} /$ day of oral minoxidil sulfate by gavage, while the control group received a correspondent amount of oral isotonic saline solution. The treatment was initiated 24 hours before the operation and continued until the $7^{\text {th }}$ post-operative day. Rats were anesthetized with intramuscular injections of a mixture of ketamine $(50 \mathrm{mg} / \mathrm{ml})$ and $1 \mathrm{ml}$ of xylasine $(0.2 \mathrm{ml} / 100 \mathrm{~g}$ of weight). Half of the initial dose was used as needed during the procedure. In each animal, after tricotomy and assepsy a 4x8 cutaneous flap was designed according to Petry and Wortham $^{(11)}$ and modified by Biondo-Simões et al. ${ }^{(12)}$ with a special skin on the ventral abdominal wall. The medial limit of the flap was the medial abdominal line and the inferior limit was the superior edge of the pubis. The design of the ventral abdominal wall cutaneous flap was performed, using a mold previously prepared with $8 \mathrm{~cm}$ of length for $4 \mathrm{~cm}$ of width, as described by Petry and modified by BiondoSimões. The medial limit of the mold was put on the midline of the ventral abdominal wall, and the inferior limit of the flap at the pubis. After that the flap was drawn using the mold. Eight points were symmetrically distributed on the flap: 1) The medial points: M1, M2, M3 and M4, which started $1 \mathrm{~cm}$ from midline and $1 \mathrm{~cm}$ from inferior border of the flap, and $1 \mathrm{~cm}$ apart from other point; and 2) The lateral points, which where four points localized $1 \mathrm{~cm}$ from the lateral limit of the flap and $1 \mathrm{~cm}$ from the inferior limit: L1, L2, L3 and L4. Laser fluxometry was taken over these points. (Figure 1).

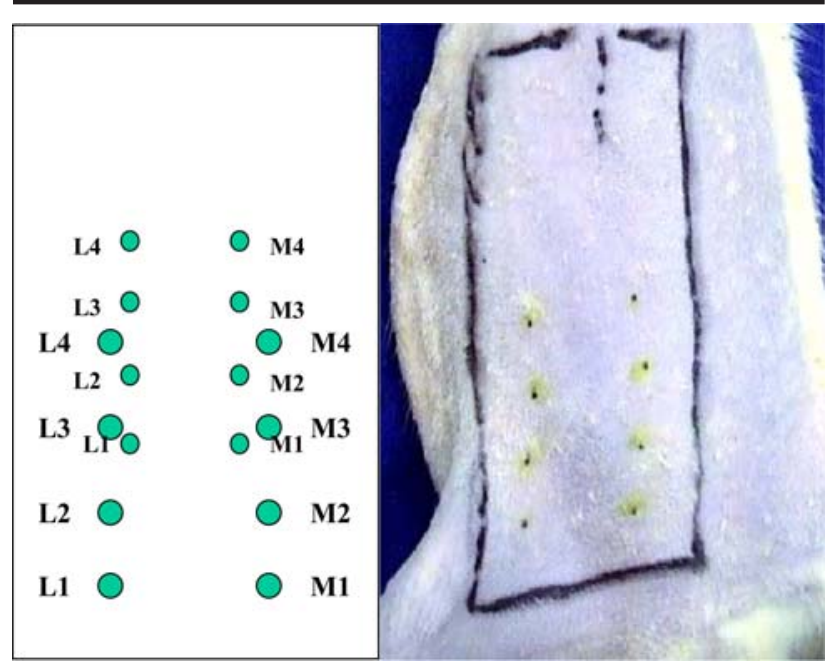

FIGURE 1 - Aspects of the draw of the flap. Left: the mold. Right: demarcation on the skin of the rat and the points for blood flow measurement.

An incision of the skin and subcutaneous tissue was made on the medial, inferior and lateral lines of the previous described draw. A flap of the fascia of the ventral abdominal muscles was dissected out up to the identification of the major division of the right caudal epigastric artery and its lateral and medial branches, which were dissected and tied up with mononylon 6.0. After its complete dissection, the flap's blood supply consisted only of the cranial epigastric artery (Figure 2).

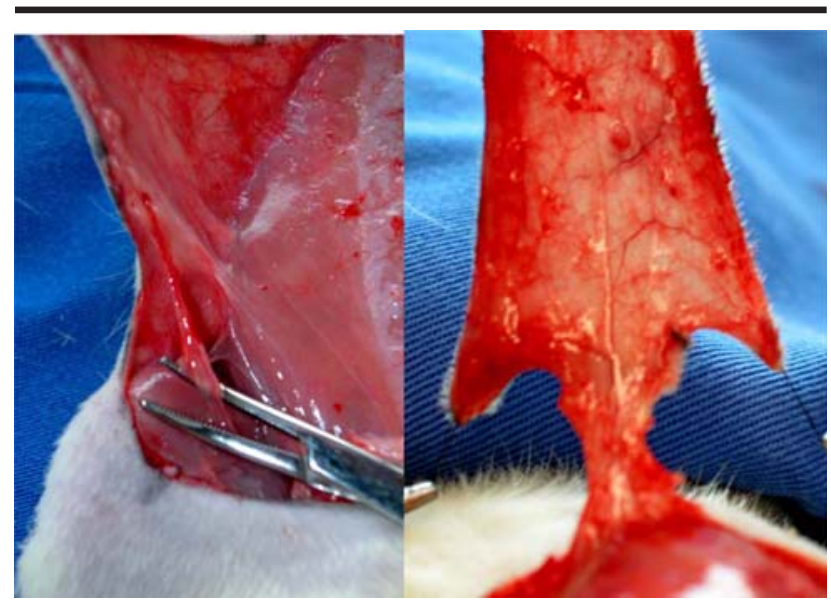

FIGURE 2 - Details of flap dissection. Right: inferior epigastric artery. Left: superior epigastric artery as pedicle. 
The flap was placed on the dissected area and fixed with distribution points of mononylon 5.0. Ultimately the synthesis of the remaining flap was performed, with mononylon 6.0. The blood flow to the flap was analyzed 24 hours before the operation and before introducing the medication by laser fluxometry (Laserflo BPM2 (Vasmedics $\left.{ }^{\circledR}\right)$, observing the 8 pre-described points, in order to access the normal blood flow of each animal. This method uses laser technology, which is able to analyze aproximately 1.0 to $1.5 \mathrm{~mm}$ of the depth in the majority of biological tissues. The analysis is performed by the detection of the flow of red blood cells by $\mathrm{ml}$ of blood that flows in a minute, divided by a $100 \mathrm{~g}$ of tissue $(\mathrm{ml} / \mathrm{min} /$ $100 \mathrm{~g})$. Twenty four hours and seven days after the procedure, the same 8 points were evaluated by laser fluxometry. The fluxometer was suspended over each of the pre-marked points on the abdominal region of the animal. The evaluation of the necrosis area was performed by measuring the necrotic area, dividing it by the flap area, and multiplying it by 100; and the result is the percentage of loss of the flap. The molds of the flap, and their corresponding necrotic areas were scanned with a multifunction $\mathrm{HP}^{\circledR} \mathrm{R} 15$ printer. The areas of the images were analyzed with the program Paint $^{\circledR}$ and Autocad ${ }^{\circledR}$ 2002. The Autocad program produced standard scales, which allowed the verification of results of the calculation of the areas. To verify the loss of flap caused by necrosis, acetate molds of the same size of the flap were used, which were previously weighed in an electronic scale AS2000c, Marte ${ }^{\circledR}$. The necrotic area was removed and was not considered for the final analysis. The remaining part of the mold was weighed and the percentage of necrotic area of the flap was determined using proportion studies. The statistical analysis was performed using the TStudent test for the quantitative variables and independent samples, or the non-parametric Mann-Whitney test, when appropriated. The normal condition was verified by the Shapiro-Wilks test. For the comparison of categorical variables, the Fisher test was used. Significance was $\mathrm{p}<0.05$.

\section{Results}

The mean weight of the control group was 291, $68 \pm$ $26,12 \mathrm{~g}$; and of the study group was $280,29 \pm 21,96 \mathrm{~g}$. The samples were similar according to the t-student test $(p=0,3049)$. Despite the lack of a macroscopic evaluation of the vessels, it was observed that the cranial epigastric artery was vasodilated, mainly in the animals treated with Minoxidil (Figura 3). Laser fluxometry showed an increased blood flow on the lateral point (L3) $(\mathrm{p}=0.0374)$ and on the M1 point $(\mathrm{p}=0.0484)$ on the 7o. post-operative day. (Table 1). On the 1st post-operative day signs of decreased blood flow were noticeable in some flaps, especially on their coloration, which was violet on their distal part, mainly over M1 point. The changes of color to black and blue were noticeable on the 3o. and 7o. post-operative days, characterizing necrosis. The macroscopic signs of established necrosis were observed on the 7o. post-operative day, in 10 flaps of the control group and in 6 of the minoxidil group ( $\mathrm{p}=0.0433)$. The original flap consisted of an area of $32 \mathrm{~cm} 2$. Analyzing the scanned areas, it was possible to observe the necrotic area and the percentage of necrotic area. There was no significant statistical difference between the two groups $(p=0.1051)$ (Table 2). The evaluation of the necrotic area was confirmed by the analysis of the weigh of the mold of the necrotic flap. There was no significant difference between the two groups. $(\mathrm{p}=0.2799)$ (Table 3).

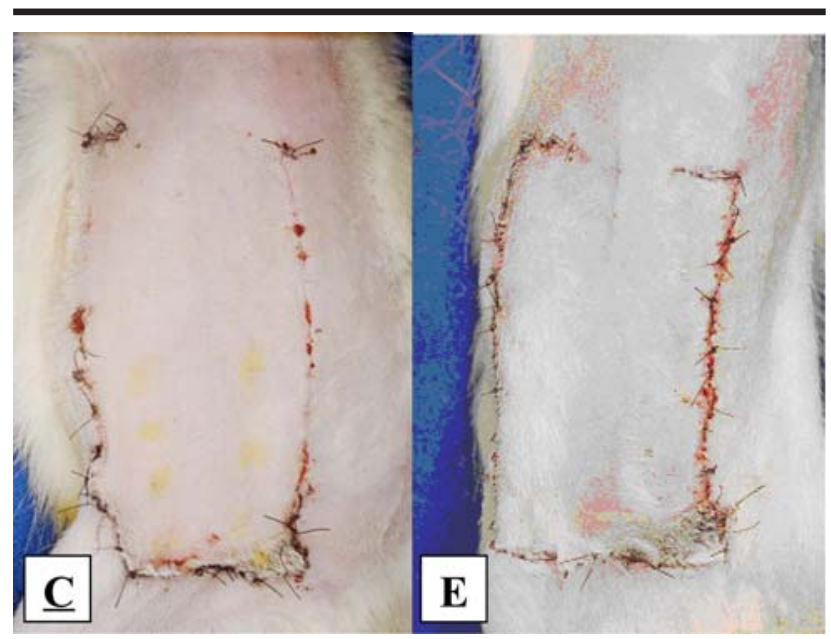

FIGURE 3 - Superior epigastric artery caliber increase in experiment group flap compared to control group. Necrosis area at inferior and medial portions of the flap.

TABLE 1 - Mean flow in every of eight points in three different moments: preoperative, first postoperative day and seventh postoperative day $(\mathrm{ml} / \mathrm{min} / 100 \mathrm{~g})$

\begin{tabular}{|c|c|c|c|c|c|c|c|}
\hline & \multicolumn{3}{|c|}{ M Group } & \multicolumn{3}{|c|}{ SF Group } & \\
\hline & $\mathrm{N}$ & Mean & $\mathrm{DP}$ & $n$ & Mean & DP & \\
\hline L1_PRE & 10 & 3.50 & 2.08 & 10 & 3.48 & 2.66 & 0.9705* \\
\hline L1_1PO & 10 & 2.65 & 1.64 & 8 & 1.59 & 1.47 & $0.1220 *$ \\
\hline L1_7PO & 10 & 2.76 & 2.72 & 9 & 1.23 & 1.75 & $0.2775^{*}$ \\
\hline L2_PRE & 9 & 6.19 & 2.80 & 8 & 6.87 & 2.53 & 0.6118 \\
\hline L2_1PO & 10 & 2.91 & 1.97 & 10 & 1.91 & 1.27 & 0.1947 \\
\hline L2_7PO & 9 & 3.47 & 2.69 & 10 & 3.37 & 2.07 & 0.9283 \\
\hline L3_PRE & 8 & 5.14 & 2.10 & 10 & 5.18 & 1.38 & 0.9599 \\
\hline L3_1PO & 9 & 4.61 & 2.52 & 10 & 3.09 & 1.08 & 0.0503 \\
\hline L3_7PO & 10 & 7,06 & 4.51 & 9 & 3.43 & 1.82 & 0.0374 \\
\hline L4_PRE & 10 & 5.099 & 2.32 & 10 & 5.01 & 2.79 & $0.2799 *$ \\
\hline L4_1PO & 10 & 6.02 & 2.12 & 10 & 5.52 & 1.72 & 0.5699 \\
\hline L4_7PO & 10 & 4.65 & 3.19 & 10 & 5.11 & 3.04 & 0.7438 \\
\hline M1_PRE & 10 & 3.86 & 1.58 & 8 & 4.22 & 1.22 & 0.6093 \\
\hline M1_1PO & 10 & 2.60 & 0.98 & 10 & 1.93 & 1.24 & 0.1957 \\
\hline M1_7PO & 9 & 2.28 & 2.56 & 9 & 0.66 & 0.99 & $0.0484 *$ \\
\hline M2_PRE & 10 & 5.82 & 2.31 & 10 & 6.07 & 1.98 & 0.7989 \\
\hline M2_1PO & 10 & 3.46 & 1.08 & 10 & 2.67 & 1.09 & $0.0753 *$ \\
\hline M2_7PO & 10 & 3.46 & 3.23 & 10 & 3.17 & 2.41 & 0.9118* \\
\hline M3_PRE & 10 & 8.00 & 3.20 & 10 & 6.28 & 1.37 & 0.1439 \\
\hline M3_1PO & 10 & 4.79 & 1.36 & 10 & 4.48 & 1.22 & $0.2475^{*}$ \\
\hline M3_7PO & 10 & 7.28 & 2.38 & 10 & 6.64 & 3.99 & 0.6686 \\
\hline M4_PRE & 8 & 7.11 & 3.84 & 10 & 7.66 & 2.76 & 0.7292 \\
\hline M4_1PO & 10 & 6.24 & 1.58 & 10 & 5.58 & 2.15 & 0.4388 \\
\hline M4_7PO & 10 & 7.06 & 3.16 & 10 & 7.38 & 4.09 & 0.8465 \\
\hline
\end{tabular}

(2) t de Student test

$\left(^{*}\right)$ Mann-Whitney test

OBS: artifacts readings have been excluded 
TABLE 2 - Necrosis area on the seventh postoperative day.

\begin{tabular}{llllll}
\hline & Control group (SF) & & \multicolumn{3}{l}{ Experiment Group (M) } \\
\hline & Necrosis area $\left(\mathrm{cm}^{2}\right)$ & $\%$ & & Necrosis area $\left(\mathrm{cm}^{2}\right)$ & $\%$ \\
\hline 01 & 1.76 & 5.50 & 02 & 0.00 & 0.00 \\
05 & 0.79 & 2.47 & 03 & 4.90 & 15.31 \\
06 & 6.81 & 21.28 & 08 & 3.94 & 12.31 \\
07 & 1.84 & 5.75 & 10 & 0.00 & 0.00 \\
09 & 2.66 & 8.31 & 11 & 0.37 & 6.06 \\
12 & 0.57 & 1.78 & 14 & 1.94 & 0.00 \\
13 & 4.08 & 12.75 & 15 & 0.00 & 0.00 \\
17 & 2.28 & 7.13 & 16 & 0.00 & 5.41 \\
20 & 3.93 & 12.28 & 18 & 1.73 & 3.81 \\
\hline Mean & 1.15 & 3.59 & 19 & 1.22 & 4.41 \\
Maximum & 2.59 & 8.08 & & 1.41 & 15.31 \\
Minimum & 0.81 & 21.28 & & 4.90 & 0.00 \\
D.P. & 190 & 1.78 & & 0.00 & 5.51 \\
\hline
\end{tabular}

Mann-Whitney test $\mathrm{p}=0,1051$

TABLE 3 - Necrosis evaluation through weight ratio.

\begin{tabular}{llllll}
\hline & Control Group (SF) & & \multicolumn{2}{l}{ Experiment Group (M) } \\
\hline & Necrosis area (g) & $\%$ & 02 & Necrosis area (g) & $\%$ \\
\hline 01 & 0.03 & 4.84 & 0.00 & 0.00 \\
04 & 0.01 & 1.61 & 03 & 0.10 & 16.13 \\
05 & 0.15 & 24.19 & 08 & 0.10 & 16.13 \\
06 & 0.04 & 6.45 & 10 & 0.00 & 0.00 \\
07 & 0.03 & 4.84 & 11 & 0.04 & 6.45 \\
09 & 0.03 & 4.84 & 14 & 0.04 & 6.45 \\
12 & 0.10 & 16.13 & 15 & 0.00 & 0.00 \\
13 & 0.07 & 11.29 & 16 & 0.00 & 0.00 \\
17 & 0.08 & 12.90 & 18 & 0.06 & 9.68 \\
20 & 0.01 & 1.61 & 19 & 0.01 & 1.61 \\
\hline Mean & 0.055 & 8.87 & & 0.035 & 5.64 \\
Median & 0.04 & 5.65 & & 0.04 & 5.65 \\
Maximum & 0.15 & 24.19 & & 0.10 & 16.13 \\
Minimum & 0.01 & 1.61 & & 0.00 & 0.00 \\
D.P. & 0.0448 & 7.22 & & 0.0403 & 6.51 \\
\hline
\end{tabular}

Mann-Whitney test $\mathrm{p}=0,2799$

\section{Discussion}

It was observed only minimal changes between the 2 groups by the laser fluxometry analysis. On the $7^{\text {th }}$ postoperative day there was a significant increase in the blood flow in the animals that received minoxidil, in the point M1 of the flap, the most distal and medial extremity of the flap, and in the point L3 (lateral and superior). However, this method of evaluation, was not considered reliable, because even over established necrotic areas it was observed the presence of blood flow, possibly indicating that there were reading artifacts, with the detection of blood vessels that were under the flap. This study used planimetry and weight/ paper ratio methods to evaluate necrosis area, and it was observed similar results in both methods. Therefore, any of these two methods can be safely used. Smith and Dolan ${ }^{(10)}$ have first used minoxidil as a vasodilator substance to prevent flap necrosis. They used topical minoxidil $2 \%$ in ischemic flaps in rats; however the results were not effective. The ineffectiveness of this substance by the topical application motivated our study, which used the same substance orally. Thomas et al.(7), have reported that minoxidil was absorbed by the gastrointestinal tract in rats, dogs and monkeys, and Pettinger ${ }^{(4)}$ have described plasma levels of this drug after 30 minutes of oral administration. This study observed arterial dilation after oral minoxidil administration. However, it is not possible to affirm that the arterial dilation was caused only by the action of minoxidil, because the arterial dilation was also observed macroscopically in the control group, which received only 
saline solution, therefore these results could be associated with autonomization, as a response to ischemia. It has been shown that 4 out of 10 flaps that were treated with minoxidil didn't show necrosis and this was statistically significant $(\mathrm{p}<0.05)$. The survival area, analyzed by planimetry, showed $91.02 \%$ of survival for the control group and $95.59 \%$ for the minoxidil group, however this difference was not statistically significant. These results are possibly biased by the small sample of animals. If we remove from the analysis the 4 flaps that didn't present necrosis, it is observed that the mean area of necrosis is 7.34, which is similar to that of the control group (8,08\%). Therefore, we believe that minoxidil is effective for the prevention of the development of necrosis, because $40 \%$ of the flaps of the animals treated with minoxidil necrosis were prevented. The route of the administration of minoxidil, which was different from that used by Smith and Dolan ${ }^{(10)}$, was possibly the main factor for the positive results seen in our study. We observed that once necrosis developed, there is no significant difference in length of necrosis between the study (minoxidil) and control groups. Further studies are necessary, using different flaps, routes of application and different doses, to understand the effectiveness of minoxidil.

\section{Conclusion}

The use of minoxidil is effective to prevent the establishment of necrosis in potentially ischemic flaps in rats. However, when the ischemic process is present there is no difference in flap survival area between experimental and control groups, with the dose and route used in this study.

\section{Referências}

1. Rohrich RJ, Cherry GW, Spira M. Enhancement of skinflap survival using nitroglycerin ointment. Plast Reconstr Surg. 1984; 73(6):943-8.

2. Miller DD, Love DW. Evaluation of minoxidil. Am J Hosp Pharmacol. 1980,37(6):808-14.

3. Koch-Weser J. Vasodilatador drugs in the treatment of hipertension. Arch Intern Med. 1974; 133(6):1017-27.

4. Pettinger WA: Minoxidil and the treatment of severe hypertension. N. Engl J Med. 1980; 303(6):922-6.

5. Price VH. Topical minoxidil (3\%) in extensive alopecia areata, including long-term efficacy. J Am Acad Dermatol. 1987;16(3 Pt 2):737-44.

6. Pluss RG, Orcutt J, Chidsey CA. Tissue distribution and hypotensive effects of minoxidil in normotensive rats. $\mathrm{J}$ Lab Clin Med. 1972; 79(4):639-47.

7. Thomas RC, Hsi RS, Harpootlian H, Judy RW. Metabolism of minoxidil, a new hipotensive agent I. absorption, distribution, and excretion following administration to rats, dogs and monkeys. J Pharmacol Sci. 1975; 64(8):1360-6.

8. Thomas RC, Harpootlian H. Metabolism of minoxidil, a new hipotensive agent II. biotransformation following oral administration to rats, dogs and monkeys. J Pharmacol Sci.1975; 64(8):1366-71.

9. Johnston C.I. Effect of antihypertensive drugs on the renin-angiotensin system. Drugs. 1976;12: 274-91.

10. Smith DK, Dolan RW. Effects of vasoactive topical agents on the survival of dorsal skin flaps in rats. Otolaringol Head Neck Surg. 1999;121(3):220-3.

11. Petry JJ, Wortham KA. The anatomy of the epigastric flap in the experimental rat. Plast Reconst Surg. 1984;74(3):410-3.

12. Biondo-Simões MLP, Greca FH, Brunginski de Paula J, Chin EWK, Andrade dos Santos EA, Stalhschmidt FL. Influência do buflomedil em retalhos cutâneos isquêmicos: estudo experimental em ratos. Acta Cir Bras. 2000; 15 (supl 3): 36-40.

\section{Correpondence:}

Rogério de Castro Bittencourt

Rua Gastão Câmara, 499/252

80730-300 Curitiba-PR Brazil

Phone: (55 41)9972-0913

rogeriobittencourt8@hotmail.com
Conflict of interest: none Financial source: none

Received: May 11, 2005

Review: June 14, 2005

Accepted: July 12, 2005

\section{How to cite this article:}

Bittencourt RC, Biondo-Simões MLP, Paula B, Martynetz J, Groth A. Influence of minoxidil on ischemic cutaneous flaps in rats. Acta Cir Bras. [serial on the Internet] 2005 Nov-Dec;20(6). Available from URL: http://www.scielo.br/acb.

*Color figures available www.scielo.br/acb 